\title{
Furan toxicity on testes and protective role of lycopene in diabetic rats
}

\author{
Özlem Kara, Hatice Baş, Dilek Pandır \\ Department of Biology, Bozok University School of Arts and Science, Yozgat, Turkey
}

\begin{abstract}
Objective: Furan $\left(\mathrm{C}_{4} \mathrm{H}_{4} \mathrm{O}\right)$ is a heat-induced food contaminant that is utilized as an industrial chemical agent. Lycopene is a natural substance that is produced by plants and tomatoes. We aimed to evaluate the toxicity of furan on testes and the protective effect of lycopene in diabetic rats. Material and Methods: Male Wistar albino rats were divided into five groups: Group 1 (control group) received $1 \mathrm{~mL} / \mathrm{kg}$ corn oil. Group 2 (diabetic control group) received $55 \mathrm{mg} / \mathrm{kg} \mathrm{STZ}$ and $1 \mathrm{~mL} / \mathrm{kg}$ corn oil. Group 3 (diabetic lycopene group) received $55 \mathrm{mg} / \mathrm{kg} \mathrm{STZ} \mathrm{and} 4 \mathrm{mg} / \mathrm{kg}$ lycopene. Group 4 (diabetic furan group) received $55 \mathrm{mg} / \mathrm{kg} \mathrm{STZ}$ and $40 \mathrm{mg} / \mathrm{kg}$ furan. Group 5 (diabetic furan + lycopene group) received 55 $\mathrm{mg} / \mathrm{kg} \mathrm{STZ}, 40 \mathrm{mg} / \mathrm{kg}$ furan, and $4 \mathrm{mg} / \mathrm{kg}$ lycopene. After 28 days, the testes were extirpated in all groups. In the testicular tissue samples, the level of malondialdehyde (MDA) and the activities of catalase (CAT), glutathione peroxidase (GPx), superoxide dismutase (SOD), and reducted glutathione (GST) were studied. Serum follicle-stimulating hormone (FSH), luteinizing hormone (LH), and testosterone levels were measured. Histopathologic examination was performed by light microscope.
\end{abstract}

Results: The MDA level and the activities of CAT, GPx, SOD, and GST were found to be higher in the furan group than in the control and diabetic control groups $(\mathrm{p}<0.05)$. The MDA level and the activities of CAT, GPx, SOD, and GST were significantly lower in the furan + lycopene group than in the furan group $(\mathrm{p}<0.05)$.

Conclusion: The low blood testosterone level in the rats who received furan suggested the presence of endocrinological defects and cellular degenerative changes. Lycopene may be effective to reverse furan toxicity in diabetic rat testes. (J Turk Ger Gynecol Assoc 2016; 17: 191-6)

Keywords: Furan, rat, testis, toxicity, lycopene, diabetes mellitus

Received: 23 August, 2016 Accepted: 15 October, 2016

\section{Introduction}

Furan is a chemical agent that is used in industry for the production of organic compounds, herbicides, plastics, and pharmaceuticals (1). Coffee, canned meats, sodium caseinate, nuts, hydrolyzed soy protein, and rape seed protein are natural products that contain furan (2). However, furan should be used with caution due to potential harmful effects on adipose tissue, liver, and kidneys (3). Polychlorinated dibenzofurans accumulate in human fat tissue; if the critical range is exceeded, water enters the cells. This event leads to an increase in the production of reactive oxygen species (ROS). ROS cause mutations in protein and DNA, lipid peroxidation in membranes, apoptosis, and damage to cellular structures $(4,5)$.

The amount of oxygen is very low in the testes due to weak vascularity. Therefore, oxidative stress can be detrimental to spermatogenesis and steroidogenesis in testicular tissue. Although the testes contain low levels of oxygen, they are sensitive to oxidative stress because they contain large amounts of unsaturated fatty acids and ROS-generating systems (6). Cells produce antioxidants as protection from the harmful effects of ROS. The actions of catalase (CAT), glutathione per- oxidase (GPx), superoxide dismutase (SOD), and reducted glutathione (GST) increase in testicular tissue due to oxidative stress (7).

Lycopene is a natural substance that is found in fruits and vegetables such as tomatoes, carrots, strawberries, and cherries (8). Structurally, it is a carotenoid derivative, and it acts as a free-radical scavenger. Lycopene exhibits antioxidant activity due to its long chain and conjugated double bonds (9). Coyne et al. (10) reported increased lycopene levels in adults with type 2 diabetes mellitus; this effect was found to be associated with decreased ROS levels. Li et al. (11) investigated the effects of lycopene in diabetic patients. They found that lycopene could be used in the prevention and treatment of diabetic retinopathy. This is the first study demonstrating the effects of furan toxicity on the testes. Therefore, we aimed to assess the toxicity of furan and the protective effects of lycopene in the testes of diabetic rats.

\section{Material and Methods}

35 male adult Wistar albino rats weighing 300 to $320 \mathrm{~g}$ were obtained from the Experimental Animal Laboratory of Çukurova University. The rats were inserted into special plas- 
tic cages and were fed with free access to both water and a standard pellet diet. The study was approved by the Institutional Ethics Committee of Çukurova University.

\section{Chemicals}

In this experimental study, three substances, including streptozotosin (STZ), furan, and lycopene, were administered; all chemicals used were obtained from Sigma. Furan and lycopene were dissolved in corn oil before being administered to the animals.

\section{Implementation plan for animals}

Chemicals were administered to the rats between 9:00 A.M. and 11:00 A.M. $55 \mathrm{mg} / \mathrm{kg} \mathrm{STZ} \mathrm{was} \mathrm{given} \mathrm{to} \mathrm{each} \mathrm{rat} \mathrm{by} \mathrm{intraperitoneal}$ (ip) injection as a single dose. Two days later, the blood glycose levels of the rats were measured. Rats with a glucose range of 300 $\mathrm{mg} / \mathrm{dL}$ were accepted as diabetic. Furan was administered one hour after lycopene administration. These two substances were given to the rats by gavage once daily for 28 days.

\section{Randomization}

The animals were randomly allocated into groups. The randomization was performed using www.randomization.com. The study crew did not know which animal was in which group. The animals were divided into five groups.

\section{Study design}

Thirty-five male rats were divided into five groups: group 1 (control group) received $1 \mathrm{~mL} / \mathrm{kg}$ corn oil. Group 2 (diabetic control group) received $55 \mathrm{mg} / \mathrm{kg} \mathrm{STZ}$ and $1 \mathrm{~mL} / \mathrm{kg}$ corn oil. Group 3 (diabetic lycopene group) received $55 \mathrm{mg} / \mathrm{kg} \mathrm{STZ}$ and $4 \mathrm{mg} /$ $\mathrm{kg}$ lycopene. Group 4 (diabetic furan group) received $55 \mathrm{mg} /$ $\mathrm{kg} \mathrm{STZ}$ and $40 \mathrm{mg} / \mathrm{kg}$ furan. Group 5 (diabetic furan + lycopene group) received $55 \mathrm{mg} / \mathrm{kg} \mathrm{STZ}, 40 \mathrm{mg} / \mathrm{kg}$ furan, and $4 \mathrm{mg} / \mathrm{kg}$ lycopene. After 28 days, the testes of the rats in all groups were resected. In the testicular tissue samples, the level of MDA and the activities of CAT, GPx, SOD, and GST were studied. Serum follicle-stimulating hormone (FSH), luteinizing hormone (LH), and testosterone levels were measured. Histopathologic examination was performed by light microscope.

Ketamine hydrochloride $(100 \mathrm{mg} / \mathrm{kg}$, Alfamine, Egevet; İzmir Turkey) and xylazin hydrochloride $(10 \mathrm{mg} / \mathrm{kg}$, Xylazinbio, Intermed; Ankara, Turkey) were administered intraperitoneally for anesthesia. All the rats were allowed to breathe throughout the intervention. Ultimately, the testes were extirpated.

The testicular samples were treated with sodium phosphate solution, and the tissues were maintained at $-80^{\circ} \mathrm{C}$. The Aebi method was used to measure CAT enzyme activity (12). The Paglia and Valentine method was used to measure GPx activity (13). The Marklund and Marklund method (14) was utilized to measure SOD activity. The MDA level was assessed utilizing the test described by Ohkawa et al. (15) GST activity was determined by the Habig test (16). Protein content was evaluated by the Lowry method (17).

\section{Histopathological examination}

The testicular samples were maintained in $10 \%$ formalin solution for 1 day. Then, the tissues were dehydrated and fixed in paraffin. The thickness of the tissues was 5 to $6 \mu \mathrm{m}$. The sections were stained with hematoxylin and eosin dye. The sections were analyzed and photographed with an Olympus BX 51 light microscope (Olympus Corp.; Tokyo, Japan).

The histopathological assessment was performed as follows: grade 0 , normal; grade I, no hemorrhage and no follicular degeneration, no leukocyte infiltration, mild edema and congestion; grade II, no hemorrhage and no follicular degeneration, no leukocyte infiltration, moderate edema and congestion; grade III, severe edema and congestion, hemorrhage, follicular degeneration, and leukocyte infiltration.

\section{Statistical analysis}

The Statistical Package for the Social Sciences version 17.00 (SPSS Inc.; Chicago, IL, USA) was utilized for the statistical analyses. The homogenity of the data was evaluated with the Kolmogorov-Smirnov test. The Kruskal-Wallis test was used to evaluate the tissue damage scores and biochemical markers. $\mathrm{p}<0.05$ was accepted as significant.

\section{Results}

\section{Evaluation of biochemical parameters}

There were significant differences between the control and diabetic control groups in terms of MDA level and enzymatic activities (Figure 1).

\section{MDA level}

The MDA level was higher in the diabetic control group than in the control group $(\mathrm{p}<0.05)$. The MDA level was lower in group 3 than in group $2(\mathrm{p}<0.05)$. The MDA level was lower in group 5 than in group $4(\mathrm{p}<0.05)$ (Figure 1a).

\section{SOD activity}

SOD activity was higher in the diabetic furan group than in the diabetic control group $(\mathrm{p}<0.05)$. SOD activity was lower in group 5 than in group $4(\mathrm{p}<0.05)$ (Figure $1 \mathrm{~b})$.

\section{CAT activity}

CAT activity was greatly diminished in the diabetic furan + lycopene group compared to the diabetic furan group $(\mathrm{p}<0.05)$ (Figure 1c).

\section{GPx activity}

GPx activity was higher in group 4 than in group $2(\mathrm{p}<0.05)$. Group 5 had higher GPx activity than group $4(\mathrm{p}<0.05)$ (Figure 1d).

\section{GST activity}

GST activity was found to be lower in group 5 than in group 4 $(\mathrm{p}<0.05)$ (Figure 1e).

Effects of furan and lycopene treatment on plasma hormone levels

\section{Plasma FSH level}

When plasma FSH levels were compared, a statistically significant decrease was found in group 4 compared to group 5 $(\mathrm{p}<0.05)$ 

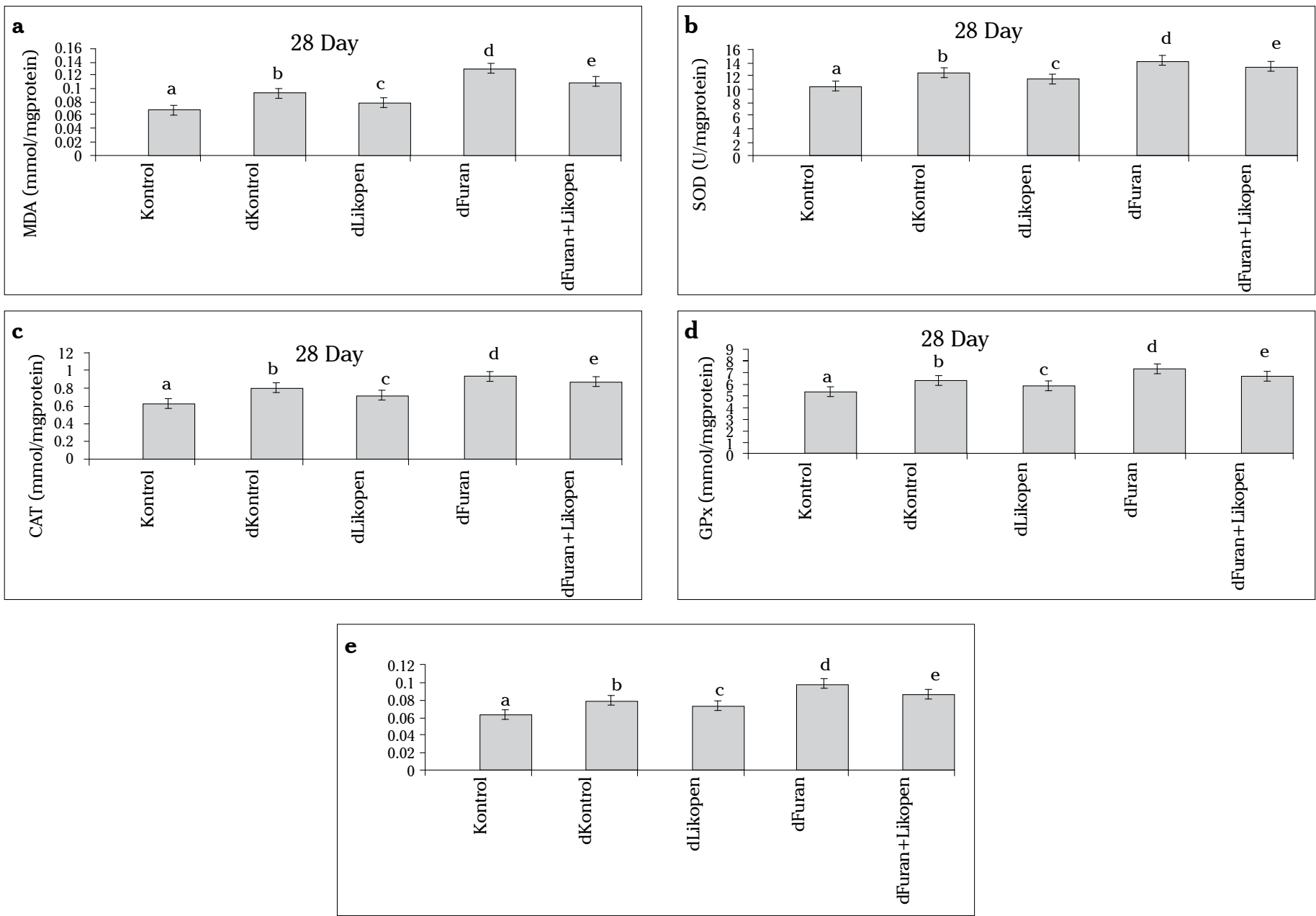

Figure 1. a-e. Comparison of the MDA level (a) and SOD (b), CAT (c), GPx (d), and GST activities in the testes of the control and experimental groups.

Table 1. Mean hormone levels between control and experimental groups

\begin{tabular}{|l|c|c|c|c|}
\hline Group & $\begin{array}{c}\text { FSH } \\
(\mathbf{m l U} / \mathbf{m L})\end{array}$ & $\begin{array}{c}\mathbf{L H} \\
(\mathbf{m l} \mathbf{U} / \mathbf{m L})\end{array}$ & $\begin{array}{c}\text { Testosterone } \\
(\mathbf{n g} / \mathbf{m L})\end{array}$ & $\mathbf{p}$ \\
\hline Control & $3.32 \pm 0.03$ & $1.42 \pm 0.021$ & $4.04 \pm 0.06^{\mathrm{a}}$ & 0.89 \\
\hline Diabetic control & $3.21 \pm 0.02$ & $1.29 \pm 0.035$ & $3.93 \pm 0.02$ & 0.57 \\
\hline Diabetic lycopene & $3.26 \pm 0.02$ & $1.36 \pm 0.024$ & $3.85 \pm 0.04$ & 0.13 \\
\hline Diabetic furan & $2.67 \pm 0.05^{*}$ & $0.88 \pm 0.047^{*}$ & $2.81 \pm 0.03^{*}$ & $0.01^{\mathrm{a}}$ \\
\hline $\begin{array}{l}\text { Diabetic furan + } \\
\text { lycopene }\end{array}$ & $2.81 \pm 0.07$ & $0.97 \pm 0.033$ & $2.96 \pm 0.08$ & 0.94 \\
\hline $\begin{array}{l}\text { FSH: follicle-stimulating hormone; LH: luteinizing hormone } \\
\text { *Statistically significant. } \\
\text { aKruskal-Wallis test was used. }\end{array}$ & \\
\hline
\end{tabular}

\section{Plasma LH level}

The lowest plasma LH level was in group 4; the addition of lycopene minimally increased the plasma LH level, and this difference was found to be significant $(\mathrm{p}<0.05)$.

Plasma testosterone level

The plasma testosterone range was lower in group 4 than in group $5(\mathrm{p}<0.05)$ (Table 1$)$.

\section{Evaluation of histopathological damage}

The morphology of the testicular tissue was normal in the control group (Figure 2a). After STZ administration, mild edema and vascular congestion were detected in the diabetic control group (Figure $2 b)$. The tissue of the diabetic lycopene group showed mild edema and detachments of the basal cells of the seminiferous tubules (Figure 2c). In group 4, leukocyte infiltration and edema were detected in the testicular stroma. Degeneration was observed in the seminiferous tubules and germ cells (Figure 2d). Treatment with lycopene reduced testicular tissue damage. No leukocyte infiltration, edema, hemorrhage, or follicular degeneration was observed in the diabetic furan + lycopene group (Figure $2 \mathrm{e}$ ).

The histopathological assessment was performed as follows: grade 0 , normal; grade I, no hemorrhage and no follicular degeneration, no leukocyte infiltration, mild edema and congestion; grade II, no hemorrhage and no follicular degeneration, no leukocyte infiltration, moderate edema and congestion; grade III, severe edema and congestion, hemorrhage, follicular degeneration, and leukocyte infiltration. The testicular tissue damage scores in group 5 were lower than in group 4, and this difference was found to be significant $(p<0.05)$. The control and diabetic furan + lycopene groups were the least-influenced groups; the damage scores and biochemical values were superior in these groups (Table 2). 

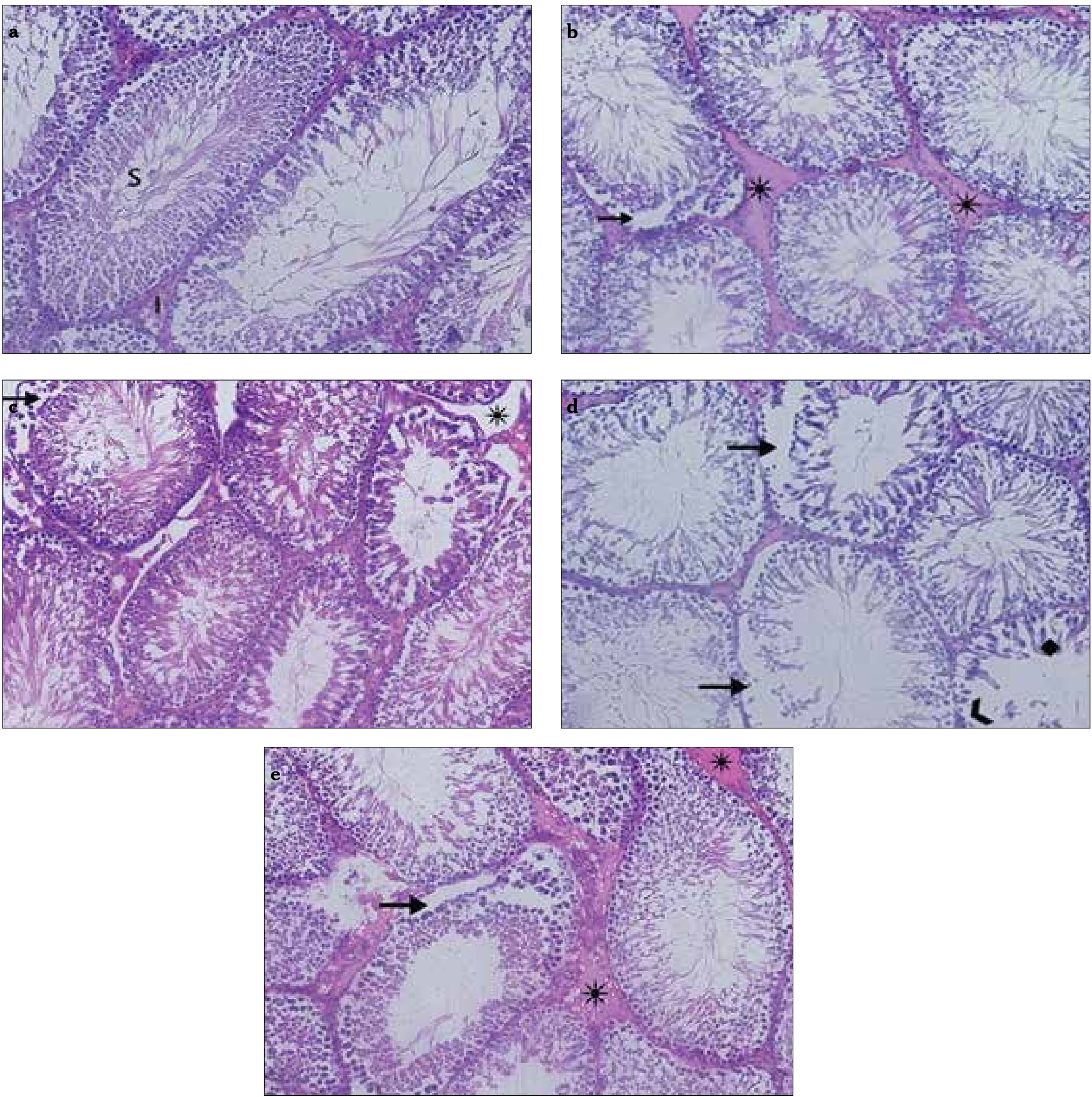

Figure 2. a-e. Appearance of testes by light microscope. Control group (a), S: seminar tubul, I: interstitial space, x200. Diabetic control group (b), (*) edema, (black arrow) separation in the basal cells of the seminiferous tubules. Diabetic lycopene group (c), (black arrow) separation in the basal cells of the seminiferous tubules, (*) edema. Diabetic furan group (d), (black arrow) separation in the basal cells of the seminiferous tubules, $(\diamond)$ degeneration, $(>)$ basal cell loss in the seminiferous tubules. Diabetic furan + lycopene group (e), (*) edema, (black arrow) separation in the basal cells of the seminiferous tubules

\section{Discussion}

In this study, the toxicity of furan and the protective effect of lycopene on the testes of diabetic rats were evaluated. The results of this study demonstrate that tissue MDA levels and the enzymatic activities of SOD, CAT, GPx, and GST appear to be elevated with furan treatment. A decrease was detected in the MDA level and enzymatic activities after supplementation with lycopene. Also, plasma FSH, LH, and testosterone levels were found to decrease when furan was administered. Lycopene 
Table 2. Distribution of histopathologic findings according to the number of animals

\begin{tabular}{|l|c|c|c|c|}
\hline \multirow{2}{*}{ Group } & \multicolumn{4}{|c|}{ Histopathological score } \\
\cline { 2 - 5 } & $\mathbf{0}$ & I & II & III \\
\hline Control & 6 & - & - & - \\
\hline Diabetic control & - & 4 & 2 & - \\
\hline Diabetic lycopene & 2 & 3 & 1 & - \\
\hline Diabetic furan & - & - & 1 & 5 \\
\hline Diabetic furan + lycopene & - & - & 5 & 1 \\
\hline
\end{tabular}

addition appears to reverse the negative effects of furan on testicular tissue. This is the first study describing the effects of lycopene on diabetic rats treated with furan.

Furan is an important environmental contaminant with a heterocyclic structure. The toxic effects of furan are well known from animal studies (1-3). Gill et al. (18) studied the toxic effects of furan on the hepatocytes of rats. They found that furan showed no adverse effects or hepatic toxicity at a dose of 0.03 $\mathrm{mg} / \mathrm{kg}$. However, we administered a furan dose of $40 \mathrm{mg} / \mathrm{kg}$ in our study. Furan is mutagenic, and some tumors have been demonstrated to be associated with furan usage $(19,20)$. Moser et al. (21) reported that oxidative stress induced by furan in cells causes an increase in ROS levels.

Studies have reported improvements in cellular and seminiferous structures by elimination of obstructions due to testicular artery ligation $(22,23)$. Oxidative stress can be detrimental to spermatogenesis and steroidogenesis in Leydig cells (7). Therefore, we believed that utilization of lycopene might protect testes from furan-induced toxicity.

Lycopene is an antioxidant that has been investigated for the prevention and treatment of oxidative stress. It neutralizes free radicals and has antioxidant properties (24). Lycopene has been demonstrated to have protective effects against breast, endometrium, and liver cancers (25). Oxidative stress due to diabetes mellitus can lead to endotelial dysfunction. Li et al. (11) showed that lycopene could repair vascular endothelial damage in diabetic patients. Coyne et al. (10) reported that lycopene and serum carotenoids could reverse the harmful effects of type 2 diabetes mellitus. In our study, control and diabetic control groups were compared in terms of antioxidant enzyme activities. The enzyme activities were significantly higher in the diabetic control group than in the control group. In the diabetic lycopene group, antioxidant enzyme activities were lower than in the diabetic control group. The light microscopic findings and hormone levels, such as FSH, LH, and testosterone, indicated cellular degenerative changes.

Testicular tissue uses different antioxidant enzymes to protect itself from damage by free radicals. These enzymes include CAT, GPx, SOD, and GST (6). Therefore, we studied the tissue MDA levels and the enzyme activities of CAT, GPx, SOD, and GST to assess the oxidative damage due to furan and the possible protective effects of lycopene. According to our results, the MDA level and CAT, GPx, SOD, and GST activities were found to be higher in group 4 than group 1 and $2(p<0.05)$. When plasma $\mathrm{FSH}, \mathrm{LH}$, and testosterone levels were compared, they were lower in group 4 than in the other groups $(\mathrm{p}<0.05)$.
Although these findings are short term, the results could ultimately be useful to protect the testes of diabetic rats from furan toxicity. However, large-scale randomized studies are needed to evaluate the protective effects of lycopene on furan damage in the testis.

Ethics Committee Approval: Ethics committee approval was received for this study from the ethics committee of Çukurova University (09/12/2013/11).

\section{Informed Consent: N/A.}

Peer-review: Externally peer-reviewed.

Author Contributions: Concept - Ö.K., D.P.; Design - Ö.K.,D.P.; Supervision - Ö.K., H.B., D.P.; Resources - Ö.K., H.B.; Materials - Ö.K., H.B.; Data Collection and/or Processing - O.K., H.B.; Analysis and/or Interpretation - Ö.K., H.B.; Literature Search - Ö.K., H.B.; Writing Manuscript - Ö.K., H.B., D.P.; Critical Review - Ö.K., H.B., D.P.

Conflict of Interest: No conflict of interest was declared by the authors.

Financial Disclosure: The authors declared that this study has received no financial support.

\section{References}

1. Lynne WE, Alphonse ES. Phenotypic caracterization of metaplastic intestinal glands and ductular hepatocytes in cholangiofibrotic lesions rapidly induced in the caudate liver lobe of rats treated with furan. Cancer Res 1991; 51: 5752-9.

2. Maga JA. Furans in foods. CRC Crit Rev Food Sci Nutr 1979; 11: 355400.

3. Kedderis GL, Ploch SA. The biochemical toxicology of furan. Chemical Industry Institute of Toxicol 1999; 19:1-8.

4. Parlakpinar H, Sahna E, Acet A, Mizrak B, Polat A. Protective effect of caffeic acid phenethyl ester (CAPE) on myocardial ischemiareperfusion induced apoptotic cell death. Toxicol 2005; 209:1-14.

5. Peterson LA, Cummings ME, Chan JY, Vu CC, Mateer BA. Identification of a cis- 2- butene-1,4 -dial-derived glutathione conjugate in the urine of furan- treated rats, Chemical Research in Toxicol 2006; 19: 1138-41.

6. Atiken RJ, Roman SD. Antioxidant systems and oxidative stress in the testes. Oxid Med Cell Longev 2008; 1: 15-24.

7. Peltola V, Huhtaniemi I, Ahotupa M. Antioxidant enzyme activity in the maturing rat testis. J Androl 1992; 13: 450-5.

8. Hadley CW, Clinton SK, Schwartz SJ. The consumption of processed tomato products enhances plasma lycopene concentretions in association with a reduced lipoprotein sensitivity to oxidative damage. J Nutr 2003; 133: 727-32.

9. Bast A, Haenen GR, Van Den Berg R, Van Den Berg H. Antioxidant effects of carotenoids. Int J Vitam Nutr Res 1998; 68: 399-403.

10. Coyne T, Ibiebele TI, Baade PD, Dobson A, Mc Clintock C, Dunn S, et al. Diabetes mellitus and serum carotenoids: findings of a population-based study in Queensland, Australia. Am J Clin Nutr 2005; 82: 685-93.

11. Li ZZ, Lu XZ, Ma CC, Chen L. Serum lycopene levels in patients with diabetic retinopathy. Eur J Ophthalmol 2010; 20: 719-23.

12. Aebi H. Catalase in vitro. Methods Enzymol 1984; 105: 121-6.

13. Paglia DE, Valentine WN. Studies on the quantitative and qualitative characterization of glutathione peroxidase. J Lab Med 1987; 70 : $158-65$.

14. Marklund S, Marklund G. Involvement of the superoxide anion radical in the autoxidation of pyrogallol and a convenient assay for superoxide dismutase. Eur J Biochem 1974; 47: 469-74. 
15. Ohkawa H, Ohishi N, Yagi K. Assay for lipid peroxides in animal tissues by thiobarbituric acid rection. Anal Biochem 1979; 95: 351-8.

16. Habig WH, Pabst MJ, Jakoby WB. Glutathione-S-transferases: the first enzymatic step in mercapturic acid formation. J Biol Chem 1974; 249: 7130-9.

17. Lowry OH, Rosebrough NJ, Farr AL, Randall RJ. Protein measurement with the Folin phenol reagent. J Biol Chem 1951; 193: 265-75.

18. Gill S, Bondy G, Lefebvre DE, Becalski A, Kavanagh M, Hou Y, et al. Subchronic oral toxicity study of furan in Fischer-344 rats. Toxicol Pathol 2010; 38: 619-30.

19. Perez Locas C, Yaylayan VA. Origin and mechanistic pathways of formation of the parent furan, a food toxicant. J Agric Food Chem 2004; 52: 6830-6.

20. Mariotti MS, Toledo C, Hevia K, Gomez JP, Fromberg A, Granby K, et al. Are Chileans exposed to dietary furan? Food Addit Contam 2013; 30: $1715-21$.
21. Moser GJ, Foley J, Burnett M, Goldsworthy TL, Maronpot R. Furan induced dose-response relationships for liver cytotoxicity, cell proliferation, and tumorigenicity (furan-induced tumorigenicity). Exp Toxicol Pathol 2009; 61: 101-11.

22. Ozgur H, Kaya M, Doran SS. Ultrastructure of the seminiferous tubules in human testes before and after varicocelectomy. Anat Embryol 2003; 207: 343-53.

23. Kaya M. Sertoli cells and various types of multinucleates in the rat seminiferous tubules following temporary ligation of the testicular artery. J Anat 1986; 144: 15-29.

24. Hadley CW, Clinton SK, Schwartz SJ. The consumption of processed tomato products enhances plasma lycopene concentretions in association with a reduced lipoprotein sensitivity to oxidative damage. J Nutr 2003; 133: 727-32.

25. Erhardt JG, Meisner C, Bode JC. Lycopene, beta-carotene and colorectal adenomas. Am J Clin Nutr 2003; 78: 1219-24. 